\title{
Otofaji: Programlı Hücre Ölümü
}

\author{
Aynur Karadă̆ \\ Ankara Üniversitesi, Tıp Fakültesi, Tıbbi Biyoloji AD. Ankara, Türkiye \\ E-mail: aynkaradag@gmail.com
}

\begin{abstract}
Özet
Kalite kontrol sistemi olarak çalışan otofaji mekanizması, uzun ömürlü proteinlerin, fonksiyonu bozulmuș organellerin, sitozolik parçaların, hasarlı makromoleküllerin ve patojenlerin yok edilmesinden sorumlu fizyolojik bir fenomendir. otofaji Biyolojik geri dönüştürme fonksiyonuna ek olarak, obezite ve diyabet gibi metabolik sendromların patogenezinde de önemli bir rol oynamaktadır. Hücrelerin fonksiyonel olarak korunması için gerekli enerji çok fazladır ve anabolik ve katabolik metabolizma arasındaki dengedeki bozukluklar hastalıklara katkıda bulunmaktadır. Otofajinin disfonksiyonu birçok hastalığın başlamasına ve ilerlemesine neden olmaktadır. Hücresel içeriğe bağlı olarak apoptozisin yetersiz kaldığı koşullarda otofaji ile hücre ölümü gerçekleşmektedir. Bu nedenle, metabolik düzenlemede otofajinin rolü ve moleküler mekanizmaları üzerine araştırmalar gittikçe artmıştır. Bazal otofaji, tümörogenez sırasında tümör baskılayıcı bir mekanizma olarak çalışırken; aşırı otofaji belirli kanserlerde hayatta kalma yolağı olarak çalı̧̧aktadır. $\mathrm{Bu}$ alandaki araştırmalar kanser, enfeksiyonlar ve nörodejenaratif ve metabolik hastalıklar gibi sağlık problemleri için yeni tedavi yöntemlerine yol açma potansiyeline sahip olacaktır.
\end{abstract}

Anahtar Kelimeler: Otofaji, apoptozis, programlı hücre ölümü

\begin{abstract}
Working as a quality control system, autophagy is a physiological phenomenon responsible for the degradation of long lived proteins, dysfunctional organelles, cytosolic fragments, damaged marcomolecules and pathogens in cells. In addition to its biological recycling function, autophagy plays a significant role in the pathogenesis of metabolic syndromes such as obesity and diabetes. Since the energy required to maintain cell function is high, disturbances in the balance between anabolic and catabolic metabolism possibly contribute to various disorders. Dysfunction of autophagy leads to the initiation and progression of multiple diseases. Autophagy contributes to cell death depending on the cellular contents especially under conditions associated with impaired apoptosis. Therefore, there has been increasing research on the molecular mechanisms and metabolic regulation of autophagy. Basal autophagy may function as a tumor suppressive mechanism during tumorigenesis; however, excessive autophagy works as a pro-survival pathway in some cancer types. Research in this area is critical for the development of novel therapeutics in health problems such as cancer, infections, neurodegenerative and metabolic diseases.
\end{abstract}

Keywords: Autophagy, apoptosis, programmed cell death 


\section{Giriş}

Canlıların yaşam döngüsünün temel unsurları doğum, büyüme, üreme, yaşlanma ve ölümdür. Yaşamın sürdürülmesi, organizmada yapı ve fonksiyonun fizyolojik gereksinimlerin belirlediği sınırlar içinde korunmasına bağlıdır. Bunun için hücre çoğalması ve ölümü arasında bir denge bulunması gerekir. $\mathrm{Bu}$ denge kaybolduğunda, yani çoğalandan çok hücre öldüğü ya da farklılaştığında dejeneratif hastalıklar, ölen ya da farklılaşandan daha fazla hücrenin çoğalması durumunda ise kanser ve otoimmün hastalıklar görülür (Mak, 2003).

Programlı hücre ölümü çok hücreli organizmalarda evrim sürecinde korunmuş mekanizma olup, morfogenezde, doku homeostasisinde ve patojenlere karşı savunmayı da içeren bir çok temel fonksiyonda rol oynamaktadır. İlk kez 1972 yılında Kerr, Wyllie ve Currie tarafından ortaya atılmıştır. 2 tip hücre ölümü tanımlamışlardır; Apoptozisi, genetik olarak kontrol edilen hücre ölümü, nekrozisi ise programlı olmayan ve tesadüfi hücre ölümü olarak tanımlamışlardır. Bu çalışmaları takiben sonraki yıllarda apoptozis programlı hücre ölümü olarak adlandırılırken 1990 yılında Clarke'ın yaptığ1 çalıșmalarla 3 tip hücre ölümü daha tanımlanmıștır (Gözüaçık ve Kimchi, 2007). Clarke bu sınıflandırmayı embriyonik gelişim sırasındaki ve toksinlerle yaptığı muameler sonucundaki hücre ölümlerinin morfolojilerine göre yapmış olup en az 8 çeşit programlı hücre ölümünün varlığına işaret etmiştir. Morfolojik tanımlamlar ve moleküler düzeyde yapılan çalışmalar sonucu apoptoza ek veya alternatif olarak düşünülen temel ölüm yollarından birisi de otofaji olmuştur. Yapılan çalışmalar apoptozisten farklı olarak otofajinin, besin yokluğunda veya hücresel stres durumunda hücre içi moleküllerin geri dönüşümünü sağlayarak homestostazisinin korunmasında yardımcı olduğu gösterilmiştir (Galluzzi et al., 2012, Anding ve Baehrecke, 2015).

\section{Otofajik Hücre Ölümü}

Otofaji evrimsel olarak korunmuş, hücresel içeriği autophagosome olarak adlandırılan çift zarlı vezikül tarafindan saklanan ve degredasyonu lizozomal olarak yapılan, protein degredasyonu ve organel turnover gibi homeostatik fonksiyonları sürdüren katabolik bir süreçtir. Geleneksel olarak, otofaji hücresel strese yanıt olarak hücre kalite kontrolü için, hayatta kalma mekanizması olarak düşünülmektedir. Bazal otofaji, zarar görmüş organeller, uzun ömürlü proteinler ve protein agregatlarını uzaklaştırmak, besin ve büyüme faktörü eksikliği gibi hücresel strese yol açan durumlarda hızla aktive olmaktadır (Anding ve Baehrecke, 2015). Hücre içi yapılar için alternatif kaynak ve hücre yaşamının devamı için enerji üretimine substrat sağlamaktır. Hücrenin gerekli besini bulunduğu ortamdan alamaması durumunda, kendini içten yiyerek varlığını sürdürmesidir. Ayrıca otofaji patojen enfeksiyonu, hipoksi, besin azalması ya da reaktif oksijen türleri (ROS) gibi hücresel stres ile tetiklenebilir. Hücrenin zor koşullara uyumunu sağlayan bu özelliği ile yaşamsal organları tüketerek ölüme yol açmaktadır. Kontrolü bozulduğunda kanser, erken bunama, bazı kalıtsal hastalıklar, Alzheimer ve enfeksiyonların oluşmasına sebep olmaktadır (Galluzzi et al., 2012).

Çalışmaların çoğu açlık tarafından tetiklenen, hücre sağkalımında otofajinin fonksiyonu üzerine odaklanmıștır. Bununla birlikte, otofaji, apoptoz ya da diğer hücre ölüm yolları veya bağımsız bir şekilde ölüm süreçleri ile sıkı bir şekilde bağlantılıdır. Nomenklatür Komitesi (NCCD), hücre ölümü araştırma alanında önde gelen araştırmacılardan oluşan bir grup, otofaji ilişkili hücre ölümü ile "otofajik hücre ölümü" olarak adlandırılmıştır (Galluzzi et al., 2012).

Otofaji, hücrelerin hücre içi besin ve enerji üretimine ihtiyacı olduğunda hızla aktive edilir. Dolayısıyla hücre yoğunluğu, oksijen konsantrasyonu, sıcaklık, hormonal faktörler ve besin durumu otofajinin kontrolünde önemlidir. Hücre ve dokuların morfolojik analizleri bir çok organizmada gelişimsel hücre ölümü sırasında otofajik aktivitenin arttığını göstermiştir. İnsect metamorfozu, kuşlardaki kol kanat morfogenezi, memelilerdeki damak kapanması sırasındaki hücre ölümleri buna örnek verilebilir. Önemli toksinler de otofajik hücre ölümünün üstün yapısal özellikleriyle hücre ölümüne neden olmaktadırlar. Her ne kadar otofajik aktivite ve hücre ölümü arasındaki rastlantısal 
ilişki tespit edilememiş olsa da ve sadece gözlemleme seviyesinde kalınsa da bu çalışmalar otofajik aktivitenin hücre ölümü üzerine etkisini dikkatle incelenmesine yol açmıştır (Anding ve Baehrecke, 2015).

Otofajik hücre ölümü Tip II hücre ölümü olarak tanımlanmış olup bu hücre ölüm tipindeki en büyük morfolojik değişiklik mitokondri ve endoplazmik retikulum gibi organeller ve/veya sitoplazmanın bir kısmının çift veya çok membranlı veziküller içine alınmasıdır. Bu veziküller lizozomlarla kaynaşırlar ve aynı hücrenin lizozomal enzimleri tarafından degredasyonu yapılmaktadır. Bu işlem Yunanca'da 'self-eating' anlamina gelen 'kendi kendini yeme' terimi olan otofaji olarak adlandırılmaktadır. Hücrenin açlıkla karşı karşıya kaldığı koşullarda besin ve enerji elde etmek için hücre içindeki yapıları parçaladığını ifade etmek için kullanılmıştır (Mizushima et al., 2008, Gözüaçık ve Kimchi, 2007).

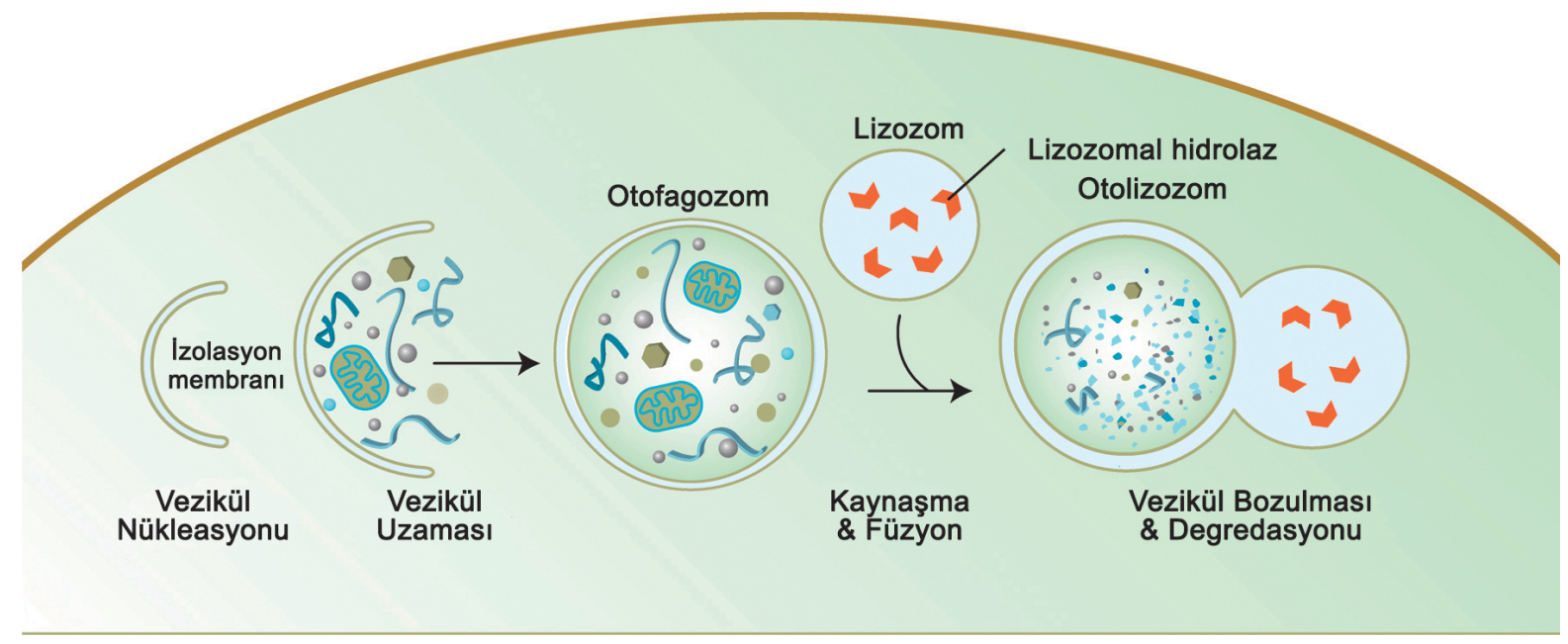

Şekil1. Otofaji aşamalarının şematik gösterimi (Mendelez ve Levine, 2009)

Otofajide, otofagozom veya otofajik vakuol olarak bilinen çift veya daha fazla membran yapıları oluşur. Memelilerde otofagozomun dış membranı lizozomla, maya ve bitkilerde ise vakuolle kaynaşır (Şekil 1) (Levine ve Yuan, 2005, Mehrpour et al., 2010). Yapılan çalışmalarda özel koşullar altında uyaranın özelliğine bağlı olarak, büyüklüğü ve süresi otofajinin uzatılması hücreyi ölüme götürebilir. Kromatin kondensasyonu gibi nükleer değişiklikler otofajik hücre ölümünde apoptoziste olduğundan sonra gözlenmektedir ve DNA fragmentasyonu ve apoptotik cisimciklerin oluşumu yoktur. Fagositoz tarafindan ölü hücrelerin temizlenmesi apoptoziste görülenden daha geç ve oldukça düzensiz olarak meydana gelebilmektedir (Shintani ve Klionsky, 2004, Gozuacik ve Kimchi, 2007).

Otofaji üç farklı şekilde gerçekleşebilir. 1) Mikro otofaji: Küçük parçacıkların membranda oluşan girintiyle lizozom içine alınıp degredasyonunun yapılmasıdır. 2) Makro otofaji: Otofajik hücre ölümünü oluşturan temel mekanizmadır. Daha büyük parçacıkların, organellerin otofagozom içine alınıp daha sonra lizozomlarla birleşerek meydana gelen degredasyondur. 3) Şapheron aracılı otofaji: Belli bir peptid sekanslı sitozolik proteinlerin moleküler şapheronlarla kompleks olan Hsp73 tarafından tanınması ve lizozomlara taşınmasıdır (Şekil 2). Bu tip protein degredasyon yolağında veziküler bir trafiğe gerek yoktur (Majeski ve Dice, 2004, Shintani ve Klionsky, 2004, Kroemer ve ark, 2010, Mehrpour et al., 2010 ). 


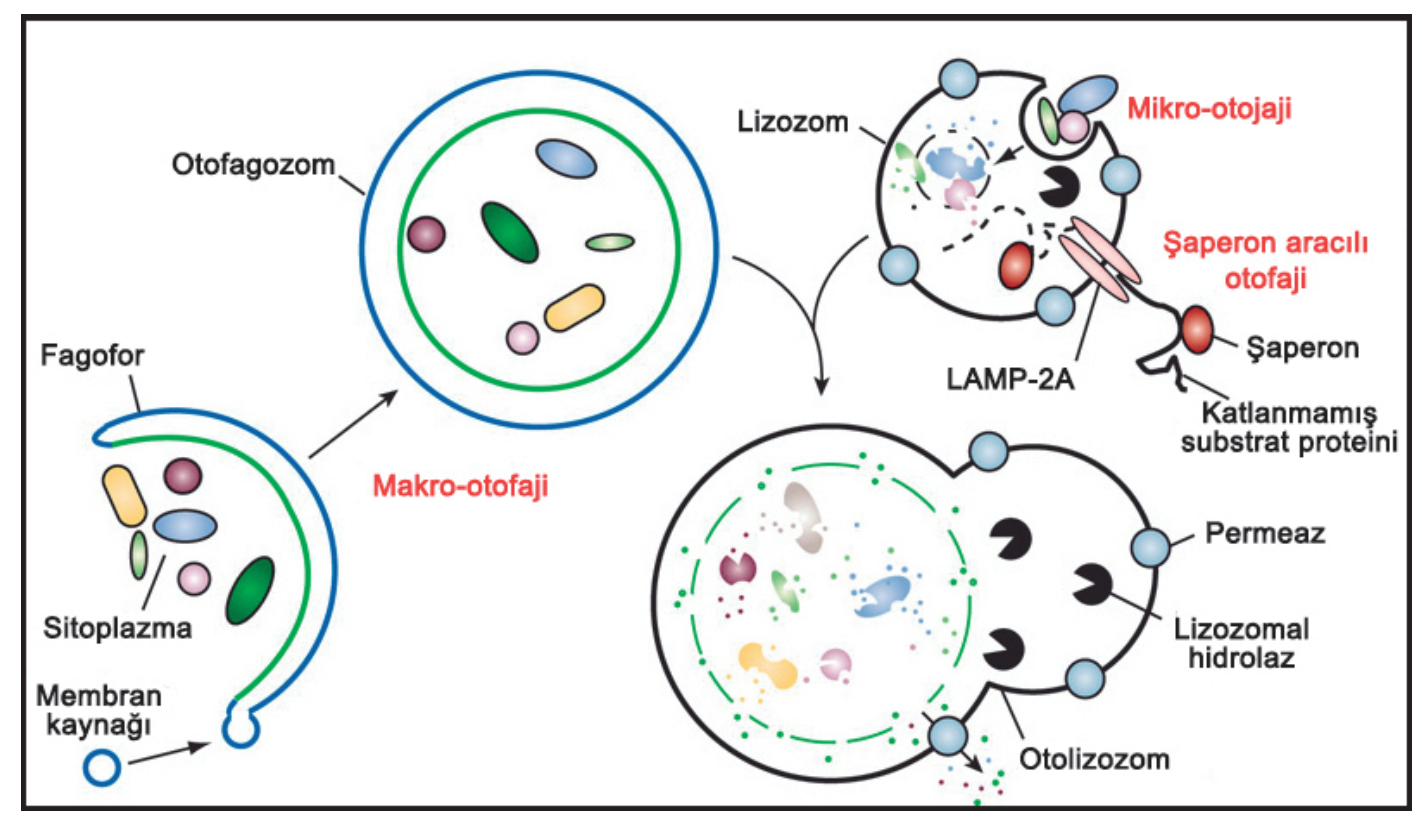

Şekil 2. Otofajinin farklı tipleri (Mizushima et al., 2008)

Yapılan çalışmalarda temel mekanizmayı oluşturan genler farklı isimler almışlardır. APG, AUT ve CVT genleri olarak bilinen genler, nomenklature göre ATG genleri (autophagy-related genes) olarak adlandırılmıştır. Otofaji sürecinin farklı aşamalarında, örneğin vezikül oluşumu ve bunların genişlemesi, otofajik veziküllerin lizozomlarla füzyonu ve degredasyonda görev alan yaklaşık 30 proteini içeren bir gen ailesidir. Otofaji proteinlerini kodlayan maya genlerinin çoğu C. Elegans genomu ile ortologdur (ATG2, ATG3, ATG4, ATG5, ATG6, ATG7, ATG8, ATG9, ATG10, ATG12, ATG16, ATG18 genleri). Otofaji fonksiyonunda, otofajinin başlamasında (unc-51/ATG1), vezikül nükleasyonunda (bec-1/ATG6, vps-34/VPS34), protein konjugasyon sisteminde (atg-7/M7.5/ATG7, lgg-1/ATG8, lgg-3/ATG12), alım ve vezikül dönüştürmede (atg-18/F41E6.13/ATG18) fonksiyon gösteren genler belirlenmiştir (Hansen et al., 2008; Hars et al., 2007; Meléndez et al., 2003). Fosfotidilinositol 3-kinazlar (PI3K) otofajik vezikül oluşumunun kontrolünde temel sinyal moleküllerdir. Otofaji, tip I ve tip III PI3K'lar tarafindan düzenlenmektedir (Xie ve Klionsky, 2007, Anding ve Baehrecke, 2015).

Otofaji en az beş adımda gerçekleşmektedir: 1) Indüksiyon 2) Genişleme 3) Tamamlama 4) Yapışma ve füzyon 5) Degredasyon. Besin azlığında otofajinin uyarılmasıyla tip I PI3K-AKT-mTOR sinyalinin inhibisyonuna ve tip III PI3K hVPS34/Beclin 1 (Drosophilada Atg6 ve Mayada Atg6/Vps30)'nın da aktivasyonuna neden olur (Juhasz et al., 2008). Otofajinin aktivasyonu için öncelikle serine/threonine kinaz Atg1'in (Memelilerde Ulk 1 ve 2) aktive olmas1 gerekmektedir. Otofajinin aktivasyonuyla beraber Atg1, Atg13 ile bir kompleks oluşturur. Bu kompleksin oluşumunun otofagozomal yapının oluşumuyla ilgili olduğu düşünülmektedir (Şekil3) (Papinski et al., 2014).

mTOR'un inhibisyonu ULK1/Atg1'i serbest brrakır, ULK1/Atg1 de mAtg9'un golgiden endosome'a yeniden dağılımını uyarır. Yine tip III PI3K hVPS34/Beclin 1 (Atg6) aktivasyonuyla da çift tabakalı membran oluşumu başlatılmış olmaktadır. Daha sonra Atg 7'nin aktivasyonuyla Atg 12 aktive olup Atg 5 ile kovalent bağ yapar bu birleşmeyle Atg 16 da bu komplekse karışarak Ag12-Atg5-Atg16 3'lü kompleksi oluşur. Oluşan bu kompleksle vezikülün genişlemesi gerçekleşir (Xiao, 2007, Anding ve Baehrecke, 2015). 


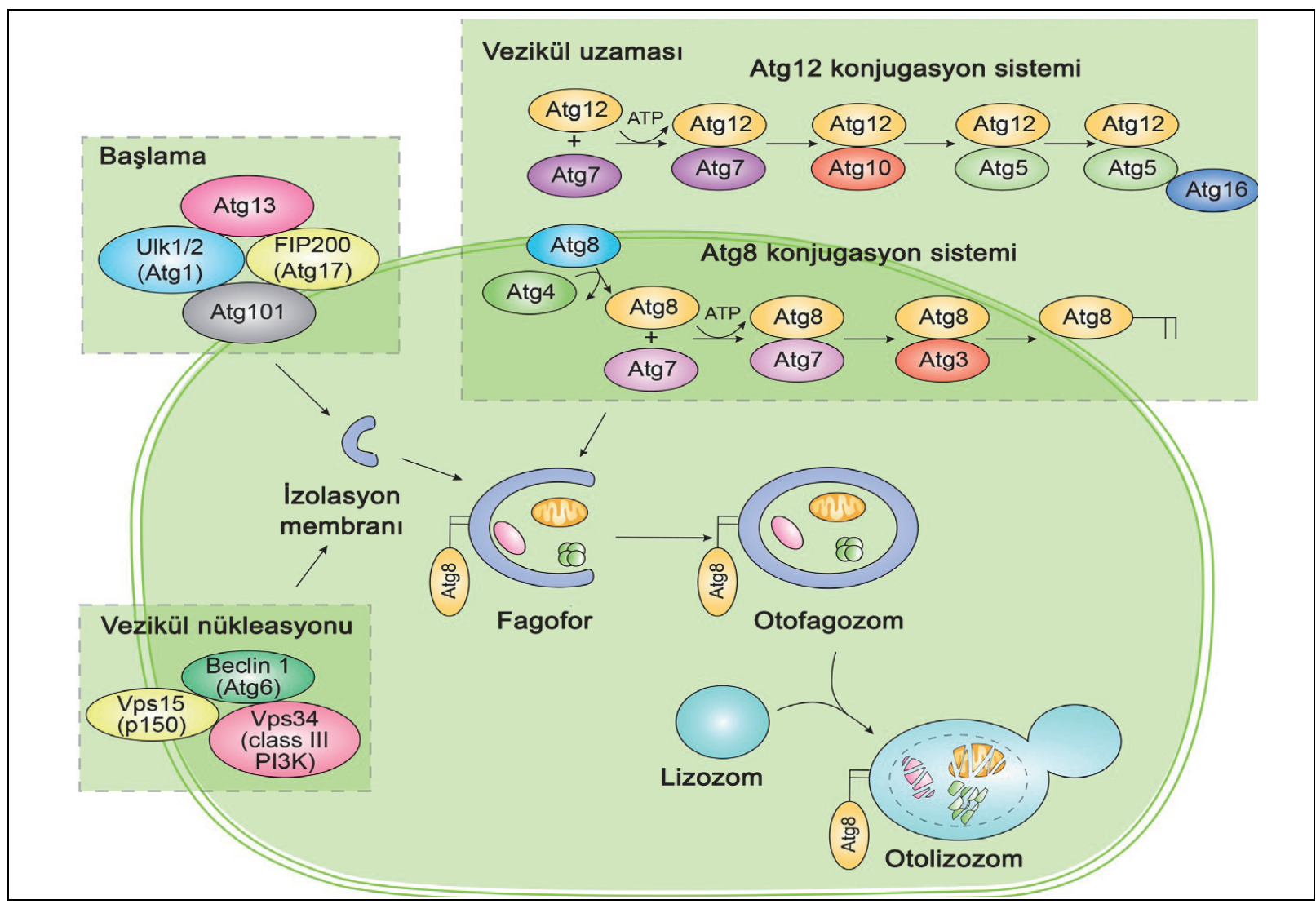

Şekil 3. Otofajinin Şematik Modeli (Anding ve Baehrecke, 2015).

Otofajinin temel mekanizması olan genlerin keşfi ilk olarak mayada çalışılmıştır. Daha sonra mayada bulunan bu genlerin homologları Dictyostelium, C. elegans, Drosophila, fare ve insanda da tanımlanmıştır. Genetik yaklaşımlar kullanılarak, otofajik genlerin susturulmasıyla, RNAi ve antisens aracılı susturma stratejileriyle hücre ölümünde otofajinin rolünün anlaşılmasında bu genlerin bulunması büyük avantaj sağlamıştır. 3MA (3-methyladenine), wortmannin ve LY294002 gibi bazı kimyasal bileşikler otofajiyi inhibe etmektedir. Bir çok bağımsız grup farklı hücre tiplerini ve ölüm uyaranlarını kullanarak lizozomal aktivitenin arttığını ve otofajik veziküllerin birikimiyle ilerleyen kaspaz bağımsız hücre ölümünün varlığını ve otofajinin inhibitörleri tarafından bu hücre ölümünün azaltıldığını göstermişlerdir (Mizushima et al., 2008). Meme kanseri hücre serisi MCF-7'nin antiöstrojenle ölüme indüklenmesi, lösemi hücrelerinin TNF- $\alpha$ ile ölüme indüklenmesi, gastrik ve glioma hücrelerinin onkogen Ras'la ölüme indüklenmesi veya büyüme faktörünün eksikliğiyle ölüme indüklenen nöronal hücreler bu çalışmalara örnek verilebilir. En yaygın otofaji inhibitörü olarak 3MA (3-methyladenine) kullanılmaktadır ve bu inhibitör JNK ve P38 aktivasyonunu da inhibe etmektedir. Mitokondrial permeabilteyi azaltırken, lizozomal pH'ı da artırmaktadır (Gözüaçık ve Kimchi, 2006).

\section{Otofajik Hücre Ölümünün Düzenleyici Mekanizmaları}

PI3 kinaz tip I insülin benzeri büyüme faktörleri tarafindan aktive edilir ve mTOR'un düzenleyicisi olan PDK 1 ve AKT üzerinden otofajiyi inhibe eder. Otofajiyi nasıl inhibe ettiği bilinmemekle beraber bir serin/treonin kinaz olan Atg 1 ile komplex oluşturan bir protein olan Atg 13'ün fosforilasyonuyla yaptığı düşünülmektedir (Gözüaçık ve Kimchi, 2006). Tümör hücresini ölüme götüren rapamycin, tamoxifen, arsenic trioxide ve radyasyon gibi birçok anti kanser ajanlar otofajiyi indükleyebilirler. PTEN, p53 ve p19ARF gibi birçok tümör baskılayıcı gen, otofajiyi aktive ederken AKT, c-Myc, PI3K ve Ras gibi birçok onkoprotein de otofajiyi baskılamaktadır (Xiao, 2007). Otofaji tümör baskılama 
mekanizmas1; genotoksik stresin azaltılması, hücre ölümünün başlatılması, nekroz ve enflamasyonun durdurulması, degrade ve modüle edici sinyal proteinlerinin düzenlenmesi gibi mekanizmalarda temel rol alır (Xiao., 2007). Aminoasit ve/veya büyüme faktörü yokluğunda otofajiyi regüle eden p53 ve mTOR yolağı arasında ise bir ilişki ortaya konmuştur. Antiapoptotik bir sinyal yolağında etkili olan mTOR aktivitesinin inhibe edilmesiyle, p53 aktivasyonu otofajiyi uyarır (Gözüaçık ve Kimchi 2006).

Mayada mitokondri dış membran proteini olan Uth1p mitokondrial otofaji için gereklidir ve bunun genlerinin inaktivasyonu Bax veya rafamisinle indüklenen hücre ölümüne direnç meydana getirmektedir. Açlık olmayan koşullar altında mayada mitokondrial bozukluklara neden olan mutasyonlar, mitokondrial membran potansiyelinin kayb1, mitokondrial biyogenezisteki defektler, mitokondrial otofajik hücre ölümünü uyardığ gösterilmiştir. Otofajide mitokondrinin eliminasyonunun artmasıyla hücre içinde ATP konsantrasyonunun da arttığı gözlenmiştir (Gözüaçık ve Kimchi, 2006, Lee et al., 2012). Memeli hücrelerinde diş mitokondriyal membranda bulunan Bcl-2 ailesi üyeleri otofajiye etki eder. Bcl-2 downregülasyonu, insan lösemi hücrelerinde kaspaz bağımsız bir yolda otofajiyi artırır. Bcl-2, belcin-1 gibi anahtar otofajik proteinlerle direk ilişkiye girerek otofajinin regülesyonunda rol oynar Bcl-2, bir otofaji proteini olan Beclin-1 ile direk bir interaksiyon yoluyla otofajiyi inhibe eder. Fakat mitokondride Bcl-2 proteinlerinin otofajiyi regüle edici işlevleri henüz tam olarak açıklanamamıştır. Bcl-2 ve Bcl-XL gibi anti-ölüm üyelerinin fazla ekspresyonu otofajik hücre ölümünden hücreleri korurken, $\mathrm{BH} 3$ domaini içeren ölüme indükleyici üyeleri olan Bax ve BNIP3 otofajik hücre ölümüne neden olmaktadır. Bax, reaktif oksijen türlerinin birikmesine, lipit peroksidasyonuna ve plazma membran değişiklerine neden olarak hücreyi ölüme götürmektedir. Yine BNIP3 ekspesyonunun artmasıyla, BNIP3 ün dimerizasyonla aktif hale geçmesi de seramid ve arsenik trioxidle otofajik hücre ölümünü uyarmaktadır (Gözüaçık ve Kimchi, 2006, Mizushima et al., 2008).

Apoptotik ve otofajik hücre ölümü arasında karşılıklı ilişkiler bulunmaktadır. Örneğin, bazı proapoptotik sinyaller (Dışsal apoptoz yolağı bileşenleri olan TRAIL, TNF ve FADD, seramid, kalsiyum-kalmodulinle regüle edilen serin-treonin kinazlar olarak bilinen DRP-1 ve DAPK1) otofajiyi indükler. Buna karşın, Sınıf I PI3K/AKT/TOR sinyalizasyonu gibi antiapoptotik sinyaller otofajiyi baskılamaktadır. Apoptozun mitokondriyal regülasyonunu sağlayan genler, otofaji yolağıyla birbirini etkileyebilir. Bu yüzden mitokondrinin, otofaji ve apoptoz yolaklarının birbirini etkilemesine neden olan bir bağlantı noktası özelliği gösterdiği düşünülmektedir (Levine ve Yuan, 2005, Mizushima et al., 2008). Hücrelerin enerji üreten motorlarında (mitokondriler) yaşlanma sürecinde oluşan bozuklukların, kanserde, beyin, sinir sistemi harabiyeti, kas ve güç kaybında rol oynadığı gösterilmektedir. Bozulup hücreye zarar vermeye başlayan mitokondriler otofaji mekanizmas1 sayesinde yok edilir. Yaşlandıkça bu sistem yavaşlamaktadır. Bozuk mitokondri birikimi artmakta, genetik yapısı zedelenen hücreler çeşitli hastalıkları tetikleyebilmektedir. Deneyler, küçük yaştan itibaren çok düşük enerjili besinlerle beslenen fare ve sıçanlarda ömrün uzadığını göstermiştir. Bunun nedenlerinin arasında bu koşullarda artan otofaji aktivitesi gelmektedir. Gelecekte ilaçlarla otofajinin etkin düzeyde sürdürülmesiyle, ileri yaşlarda yaşam kalitesi artırılabilir, hatta ömrün uzamasına yol açılabilir (Lee et al., 2012). Ancak bazı kanserlerde hücrelerin hayatta kalmak için otofajiyi kullandığ1 ve kemoterapatiklerden kaçtığ denge çok iyi korunmalıdır.

\section{Sonuç}

Programlı hücre ölüm mekanizmaları arasında son yıllarda dikkat çekmeye başlayan otofajik hücre ölümü, moleküler düzeyde elde edilen bilgiler ile hücre ölümünün nasıl kontrol edildiği konusunda yeni bilgiler kazandırmıştır. Otofaji hücrenin strese direncini artırmakta ve hayatta kalmasına yol açmaktadır. Hücre içi yıkım ve geri dönüşüm mekanizması olan otofaji bazı koşullarda ölümle birlikte seyretmesine rağmen ve otofajinin ilaçlar tarafından ya da genetik olarak bloke edilmesiyle, hücrenin 
yaşama şansı da artmaktadır. Otofaji ve otofajik hücre ölümünün moleküler mekanizmaları konusunda daha fazla ve ayrıntılı bilgi sahibi olunması, özellikle otofaji regülasyonu ve otofaji tarafindan hücrelerin nasıl öldürüldüğü konularının açıklığa kavuşturulması gereklidir.

Otofaji bozukluklarının kanser, enfeksiyon hastalıkları, nörodejeneratif hastalıklar, iskemik hastalıklar (inme, miyokart enfarktüsü) gibi pek çok hastalıkla olan bağlantısı otofaji araştırmalarının insan sağ lı̆̆ için öneminin altını çizmektedir. Bu bağlamda insan otofaji mekanizmalarının nasıl çalıştığı, nasıl regüle olduğu ve hangi sinyal yolakları tarafından kontrol edildiği konusunda çalışmalar hızla sürmektedir. Otofajinin hem temel bilimde hem de klinik bilimlerde daha iyi anlaşılması, yeni ilaç, tanı, takip ve tedavi araçlarının bulunmasına ve insan sağlığını tehdit eden önemli hastalıklara yeni, bilinçli ve moleküler temelli çözümler üretilmesine yol açacaktır. Otofaji ile apoptoz gibi programlı hücre ölümlerinin moleküler mekanizmalarının aydınlatılması, hastalıklara uygulanacak ilaç tedavilerin önünü açacaktır.

\section{Kaynaklar:}

Anding, Al., Baehrecke, E. H. (2015) Autophagy İn Cell Life And Cell Death. Apoptosis And Development. Volume 114, Pages 67-91.

Galluzzi, L., Vitale, I., Abrams, J. M., Alnemri, E. S., Baehrecke, E. H., Blagosklonny, M.V. (2012). Molecular Definitions Of Cell Death Subroutines: Recommendations Of The Nomenclature Committee On Cell Death . Cell Death And Differentiation, 19(1), 107-120.

Gözuacik, D., Kimchi, A. (2006) Dapk Protein Family And Cancer. Autophagy. 2(2):74-9.

Gözuacik, D., Kimchi, A. (2007). Autophagy And Cell Death. Curr Top Dev Biol. 78:217-45.

Hansen, M., Taubert, S., Crawford, D., Libina, N., Lee, S. J., Kenyon, C. (2007). Lifespan Extension By Conditions That İnhibit Translation İn Caenorhabditis Elegans. Aging Cell 6, 95-110.

Hars, E. S., Qi, H., Ryazanov, A. G., Jin, S., Cai, L., Hu, C., Liu, L. F. (2007). Autophagy Regulates Ageing İn C. Elegans. Autophagy 3, 93-95.

Juhasz, G., Hill, J. H., Yan, Y., Sass, M., Baehrecke, E. H., Backer, J. M., Et Al. (2008). The Class Iii Pi(3)K Vps34 Promotes Autophagy And Endocytosis But Not Tor Signaling İn Drosophila. The Journal Of Cell Biology, 181(4), 655-666.

Kroemer, G., Marino, G., Levine, B. (2010). Autophagy And İntegrated Stress Response. Mol Cell 40(2):280293.

Lee, J., Giordano, S., Zhang, J. (2012) Autophagy, Mitochondria And Oxidative Stress: Cross-Talk And Redox Signalling. Biochem J. 15;441(2):523-40.

Levine, B. Yuan, J. (2005). Autophagy İn Cell Death: An İnnocent Convict?. The Journal Of Clinical Investigation, 115 ; 2679- 2688.

Majeski, A.E, Dice, J.F. (2004) Mechanisms Of Chaperone-Mediated Autophagy. Int J Biochem Cell Biol. Dec;36(12):2435-44.

Mak, T. (2003). Apoptosis: "This Death That Makes Life Live".Biol Blood Marrow Transplant;9:483-8.

Mehrpour M, Esclatine A, Beau I, Codogno P. (2010). Overwiew Of Macroautophagy Regulation İn Mammalian Cells. Cell Research 20:748-762. 
Meléndez, A. Levine, B. Autophagy İn C. Elegans (2009), Wormbook, Ed. The C. Elegans. Research Community, Wormbook, Doi/10.1895/Wormbook.1.147.1.

Mizushima, N., Levine, B., Cuervo, A.M., Klionsky, D.J. (2008) Autophagy Fights Disease Through Cellular Self-Digestion. Nature 451, 1069-1075.

Papinski, D., Schuschnig, M., Reiter, W., Wilhelm, L., Barnes, C. A., Maiolica, A., Et Al. (2014). Early Steps İn Autophagy Depend On Direct Phosphorylation Of Atg9 By The Atg1 Kinase. Molecular Cell, 53(3), 471-483.

Shintani, T, Klionsky, D.J. (2004). Autophagy İn Health And Disease: A Double-Edged Sword. Science 2004;306:990-5.

Xiao, G., (2007).Autophagy And Nf-Kb: Fight For Fate. Cytokine Growth Factor Rev. Jun-Aug;18(3-4):233-43.

Xie, Z., Klionsky, D. J.(2007). Autophagosome Formation: Core Machinery And Adaptaion. Nat Cell Biol 9:1102-9. 